\title{
An albino armored catfish Schizolecis guntheri (Siluriformes: Loricariidae) from an Atlantic Forest coastal basin
}

\author{
Marcelo F. G. de Brito and Érica P. Caramaschi
}

\begin{abstract}
We report here on an albino specimen of Schizolecis guntheri caught in the rio Bonito in the rio Macaé basin, Rio de Janeiro State, southeastern Brazil. The hypothesis that albinism is more common in fishes with cryptobiotic and/or nocturnal habits is strengthened by additional records of this chromatic anomaly.

Relatamos aqui o albinismo em um espécime de Schizolecis guntheri capturado no rio Bonito na bacia do rio Macaé, estado do Rio de Janeiro. A hipótese do albinismo ser mais comum em peixes com hábitos criptobióticos e/ou noturnos é fortalecida por registros adicionais desta anomalia cromática.
\end{abstract}

Key words: Albinism, Hypoptopomatinae, Neotropical, rio Macaé basin, Southeastern Brazil.

Albinism, which occurs in all vertebrate groups, is a genetic disorder produced by an autosomal recessive gene in the homozygous state (Oliveira \& Foresti, 1996) and unresponsive to 1- DOPA (1-3,4- dihydroxyphenil-alanine) (Trajano \& de Pinna, 1996). Albinos are recognized by their pinkish or yellowish body color and red eyes (e.g. Sazima \& Pombal, 1986). Although albinism in fishes is rare in nature (e.g. Gudger, 1937), this chromatic anomaly has been reported in some Neotropical species. In captivity, albinos are not rare because anomalous individuals are selected by aquarium hobbyists (Sazima \& Pombal, 1984).

This paper reports on the first record of albinism in a loricariid of the subfamily Hypoptopomatinae, Schizolecis guntheri (Miranda Ribeiro, 1918).

The albino S. guntheri specimen (Fig. 1a) was caught in the rio Bonito, a tributary of the rio Macaé, near the Rio Bonito village $\left(22^{\circ} 24.765^{\prime} \mathrm{S} ; 4^{\circ} 24.494^{\prime} \mathrm{W}\right)$, southeastern Brazil, in December 2002. The studied stretch is $15 \mathrm{~m}$ wide and $87 \mathrm{~cm}$ deep. The stream bed is sandy, with boulders in the channel and gravel near the banks and the water is transparent. The vegetation along the banks consists of trees and shrubs. In some places near the river this vegetation has been cleared for a road, and there are some human dwellings along the banks. Despite the local anthropic alteration, the rio Bonito is well preserved and does not receive much discharge of organic or industrial effluents.

The albino specimen was caught at daytime, with a 5-mm mesh sieve passed through plant detritus interspersed with bamboo branches near the water surface. Five other fish species, in addition to pigmented specimens of $S$. guntheri, were caught at the same site: Characidium sp.; Acentronichthys leptos Eigenmann \& Eigenmann, 1889; Neoplecostomus microps (Steindachner, 1877); Hemipsilichthys garbei Ihering, 1911 and Phalloceros caudimaculatus (Hensel, 1868). All specimens were fixed in $4 \%$ formaldehyde and later stored in $70 \%$ ethanol. Later sampling field trips were made in November 2003, and March and May 2004, but no additional albinos were caught. Vouchers of $S$. guntheri were deposited in the Museu Nacional do Rio de Janeiro under the number MNRJ 27382.

Laboratório de Ecologia de Peixes, Departamento de Ecologia, Universidade Federal do Rio de Janeiro, Ilha do Fundão, P.O. Box 68020, 21941-541 Rio de Janeiro, RJ, Brazil. e-mail: mbrito@biologia.ufrj.br; erica@biologia.ufrj.br 


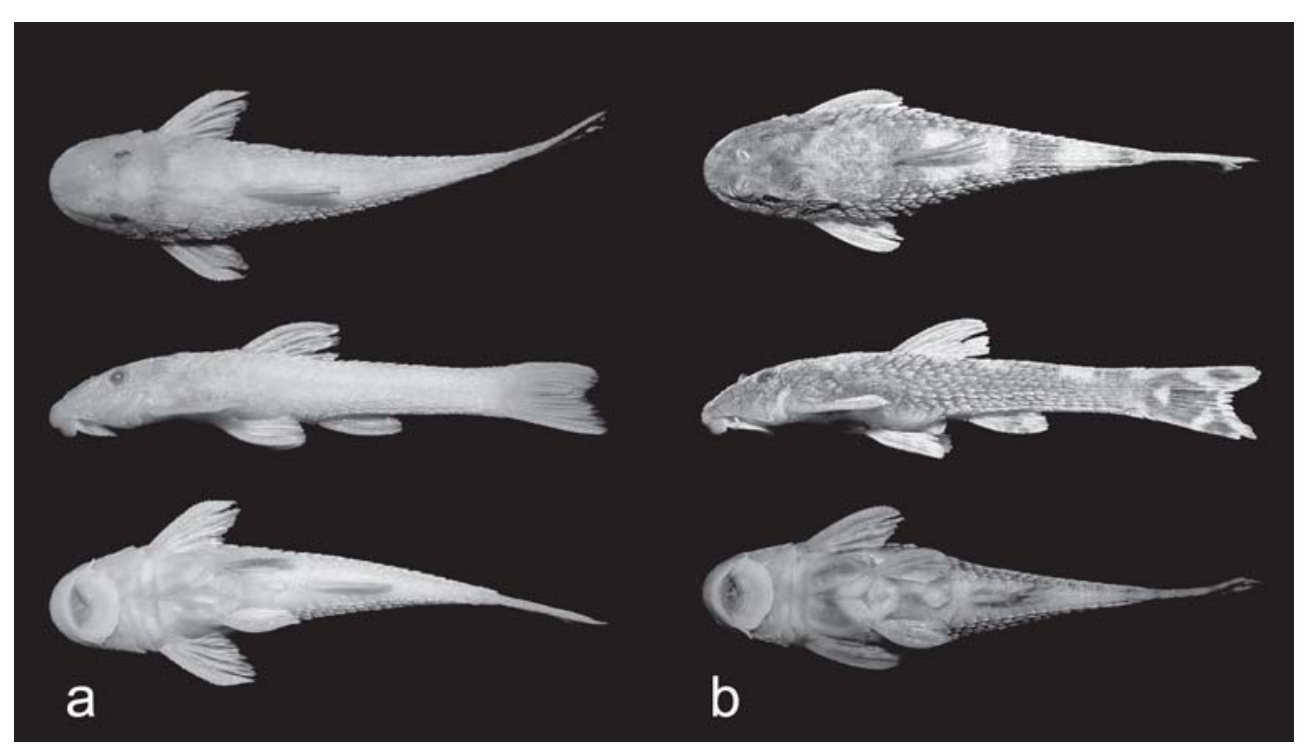

Fig. 1. Schizolecis guntheri, MNRJ 27382, (a) albino specimen, male, $30.11 \mathrm{~mm} \mathrm{SL}$; (b) pigmented specimen, female, $30.13 \mathrm{~mm}$ SL; Brazil, Rio de Janeiro State, rio Macaé basin, rio Bonito.

Schizolecis guntheri, a monotypic genus within the Hypoptopomatinae loricariids, occurs mainly in coastal rivers of the Atlantic Forest in southeastern and southern Brazil, although there are some outlying records (NEODAT, 2004). Most of the hypoptopomatine species are usually found at or near the water surface, typically in close association with riverbank vegetation or some subsurface structure (Schaefer, 2003). This habit was recorded for S. guntheri in many sites of our study in the rio Macaé basin. In addition to inherent habit, the general color of the place where the albino specimen was caught, near dry bamboo leaves and over a sandy stream bed, may provide some camouflage for this light-colored individual.

The albino specimen (an adult male, $30.11 \mathrm{~mm}$ standard length) had a pale yellow body, translucent ventral surface, unpigmented branched fin rays, hyaline membrane between the branched fin rays and reddish eyes in life, evidence of true albinism (e.g. Sazima \& Pombal, 1986). Normally pigmented specimens of $S$. guntheri have a dark background color on the body and caudal fin, with some light spots; the ventral body surface is unpigmented (Fig. 1b). Of the 61 normal specimens of $S$. guntheri caught, SL ranged 21.49 $33.32 \mathrm{~mm}$.

Sedentary fish species have a wide range of structural and color adaptations that render them cryptic in their habitat. Several species that live close to the substrate, or among floating or rooted plants, are to some degree camouflaged by their similarity with their background. However, some species are highly specialized in this regard, and through a combination of color, morphology and behavior, they become indistinguishable from their immediate surroundings (Keenleyside, 1979). The natural coloration observed in S. guntheri may be regarded as disruptive in its habitat, as showed in Buck \& Sazima (1995). The disruptive colors may hamper visually oriented aerial or aquatic predators. In the area we caught the albino, we recorded kingfishers (Chloroceryle sp.), well-known fish predators (Sick, 1997).

The incidence of albinism can be artificially increased in fish by exposing the eggs to heavy metals (e.g., arsenic, cadmium, copper, mercury, selenium, zinc) and may occur in fry originating from crosses in which adult specimens have been exposed to heavy metals (Oliveira \& Foresti, 1996). Thus, the albinism in $S$. guntheri is more probably the result of a genetic random alteration since heavy metals seems improbable in the sampled habitat.

The hypothesis that albinism in tropical fishes is commoner among nocturnal and/or cryptobiotic species than among diurnal or non-cryptobiotic ones (Sazima \& Pombal, 1986) is strengthened by further reports from freshwater habitats. Thus, the additional records of Gymnotus carapo (e.g. Campos-da-Paz \& Caramaschi, 1994) and Schizolecis guntheri (present paper), lend further support to the above mentioned hypothesis.

\section{Acknowledgments}

We thank Rafael P. Leitão, Victor T. Cardoso, Maureen Craik, José Luiz C. Novaes, Henrique L. Ameida, Danielle A. Beserra, Carla F. Rezende and Pablo H. B. Mendes for help in the field and Renata Bartolete for assistance in the laboratory. We are also grateful to Maureen Craik and her family for their hospitality in Lumiar, Luiz Henrique Rosa for the lending a photographic camera and Ricardo Campos da Paz for suggestions. Instituto Brasileiro de Meio Ambiente e de Recursos Naturais Renováveis (IBAMA) for collect permit and Conselho Nacional de Desenvolvimento Científico e Tecnológico $(\mathrm{CNPq})$ for research grants. 


\section{Literature Cited}

Buck, S. \& I. Sazima. 1995. An assemblage of mailed catfishes (Loricariidae) in southeastern Brazil: distribution, activity and feeding. Ichthyological Exploration of Freshwaters, 6(4): 325-332.

Campos-da-Paz, R. \& E. P. Caramaschi. 1994. First record of albinism in a gymnotiform fish (Teleostei: Ostariophysi). Ichthyological Exploration of Freshwaters, 5(1):1-4.

Gudger, L. 1937. An albino of tarpon, Tarpon atlanticus, the only known specimen. American Museum Novitates, 944:1-4.

Keenleyside, M. H. A. 1979. Diversity and adaptation in fish behaviour. Zoophysiology, V. 11. Springer-Verlag, New York. 208 p.

NEODAT, 2004. The Neodat Project - Database. Access in October 2004. <http://www.neodat.org/>.

Oliveira, C. \& F. Foresti. 1996. Albinism in the banded knifefish, Gymnotus carapo. Tropical Fish Hobbyist, 44(12): 92-96.
Sazima, I. \& J. P. Pombal. 1986. Um albino de Rhamdella minuta, com notas sobre comportamento (Osteichthyes, Pimelodidae). Revista Brasileira de Biologia, 46(2): 377-381.

Schaefer, S. A. 2003. Subfamily Hypoptopomatinae. Pp. 321329. In: Reis, R.E.; Kullander, S.O. \& Ferraris, C.J. (Eds). Check List of the Freshwater Fishes of South and Central America. Edipucrs, Porto Alegre, 729 p.

Sick, H. 1997. Ornitologia Brasileira. Ed. Nova Fronteira, Rio de Janeiro. 912 p.

Trajano, E. \& M. C. C. de Pinna. 1996. A new cave species of Trichomycterus from Eastern Brazil (Siluriformes, Trichomycteridae). Revue Française d'Aquariologie, 23(34):85-90.

Received September 2004 Accepted February 2005 